\title{
JAPONIA
}

\section{Edyta Nowicka}

\section{POLITYCZNE PRZEMIANY W JAPONII: EPOKA SHINZŌ ABE I DEBATY O ZMIANIE KONSTYTUCJI - ZARYS Z POŁOWY 2017 ROKU}

28 maja 2017 r. Shinzō Abe został trzecim po Eisaku Satō i Shigeru Yoshidzie najdłużej urzędującym premierem w powojennej Japonii ${ }^{1}$. Po ponad 1980 dniach u sterów rządu wyprzedził on charyzmatycznego przywódcę i własnego politycznego mentora Jun'ichirō Koizumiego, który nie tylko powierzył mu stanowisko szefa swojego gabinetu w 2005 r., lecz również wskazał jako optymalnego następcę rok później. Mimo że pierwsza kadencja rządu Shinzō Abe zakończyła się w 2007 r. jego niespodziewaną dymisją i wycofaniem z aktywnej polityki², w 2012 r. powrócił on $\mathrm{z}$ tarczą na krajową arenę, zdobywając we wrześniu nominację na przewodniczącego Partii Liberalno-Demokratycznej (Jiyūminshutō, 自由民主党), w grudniu zaś prowadząc ją do zwycięstwa w przedterminowych wyborach do Izby Reprezentantów (Shūgiin, 衆議院). Wyborczy triumf jego ugrupowania był równoznaczny z przyznaniem mu powtórnego mandatu do utworzenia rządu i zamykał tym

${ }^{1}$ Eisaku Satō - premier w latach 1964-1972 (2798 dni), Shigeru Yoshida - premier w latach 19461947 i 1948-1954 (2616 dni). Wynik Shinzō Abe obejmuje okres po 26 grudnia 2016 r., z uwzględnieniem pierwszej kadencji w latach 2006-2007, zob. Abe shushō zainin sengo san'i e [Abe jako urzędujący premier na trzeciej pozycji po wojnie], „Nikkei”, 25 maja 2017, http://www.nikkei.com/ article/DGKKZO16814500U7A520C1M11000/.

2 Analizę pierwszej kadencji rządów Shinzō Abe przedstawiłam w tekście „Piękny kraj” Shinzō Abe-japońska wizja przyszłości?, w: Krzysztof Gawlikowski, Małgorzata Ławacz (red.), Japonia na początku XXI wieku. Polityka, gospodarka, spoleczeństwo i stosunki z Polska, Wydawnictwo Adam Marszałek, Toruń 2008, s. 108-124. 
samym bezprecedensowy trzyletni rozdział administracji Partii Demokratycznej (wówczas Minshutō, 民主党) ${ }^{3}$.

Nowe polityczne rozdanie było więc dla premiera Abe swego rodzaju osobistym wyzwaniem, z którym - po latach nieobecności na scenie politycznej - zmierzył się w sposób udany. Z jednej strony odbudował bowiem silną pozycję partii i przywrócił społeczeństwu poczucie stabilności władzy po sześcioletnim okresie zmieniających się co roku gabinetów w Japonii ${ }^{4}$. Z drugiej zaś, jako wyrazisty lider, zdominował potencjalnych oponentów, stając się główną twarzą japońskiej polityki ostatnich czterech lat. Co więcej, w marcu 2017 r. stanął przed szansą pozostania w centrum życia politycznego do września $2021 \mathrm{r}$. Jest to możliwe dzięki przyjęciu przez PLD poprawki w obowiązującym od ponad czterdziestu lat regulaminie, dopuszczającej możliwość wydłużenia okresu sprawowania funkcji przewodniczącego partii z dotychczasowych dwóch do trzech kolejnych kadencji. Jeśli w 2018 r. Partia Liberalno-Demokratyczna ponownie powierzy mu partyjne przywództwo i sama utrzyma większość w wyborach parlamentarnych, przed Shinzō Abe otworzy się perspektywa pobicia w sierpniu 2019 r. rekordu długości piastowania urzędu i zapisania się na kartach historii jako najdłużej stojący u sterów państwa premier w powojennej Japonii ${ }^{5}$. Jednocześnie pozostanie na szczycie władzy w najbliższych latach umożliwi mu pracę nad realizacją jego nadrzędnego planu politycznego, jakim jest nowelizacja konstytucji ${ }^{6}$. Chęć rozpoczęcia merytorycznego dialogu i wprowadzenia w życie nowej ustawy zasadniczej w $2020 \mathrm{r}$. szef rządu publicznie ogłosił 3 maja 2017 r., czyli w dniu siedemdziesiątej rocznicy wejścia w życie konstytucji zredagowanej w warunkach powojennej okupacji ${ }^{7}$.

${ }^{3}$ Centrolewicowa PD (zob. przypis 21) w 2009 r. przejęła władzę w Japonii po historycznej wygranej w wyborach do Izby Reprezentantów, po raz pierwszy samodzielnie zdobywając bezprecedensową większość (64\%) w izbie niższej parlamentu (308 z 480 głosów). Odsunęła wówczas od władzy centroprawicową PLD, która rządziła krajem od 1955 r., z krótką przerwą w 1993 r.

4 W latach 2007-2012 w Japonii zmieniło się sześciu premierów z dwóch obozów politycznych, zob. Sengo san'i ,nagaki o motte tōtoshi to sezu” [Trzecia pozycja po wojnie „dhugo nie oznacza wartościowo”], „Nikkei”, 27 maja 2017, http://www.nikkei.com/article/DGXKZO16908780W7A520C1EA1000/.

5 Shinzō Abe może teoretycznie sprawować rządy przez 3500 dni, pobijając nawet przedwojenny rekord Tarō Katsury (premier w latach 1901-1906, 1908-1911, 1912-1913, razem 2886 dni), patrz: Jimintō, sōsaininki „renzoku sanki, kyūnen” ni enchō tōtaikai de ryōshō [Na konwencji partyjnej zatwierdzono wydłużenie kadencji przewodniczącego PLD do „trzech kadencji z rzędu, dziewięciu lat”], „Asahi”, 5 marca 2017, http://www.asahi.com/articles/ASK353DVPK35UTFK001.html.

${ }^{6}$ Poglądy Shinzō Abe na temat konieczności zmiany konstytucji szerzej omówiłam w „Piękny kraj"...

7 Obecna konstytucja została ogłoszona 3 listopada 1946 r., lecz weszła w życie 3 maja 1947 r. Z uwagi na fakt, że tekst pisano pod ścisłą kuratelą Najwyższego Dowództwa Sił Sprzymierzonych, przyjęto, że Japończycy samodzielnie przeredagują ją w czasie „,nie krótszym niż rok, lecz nie 
Poglądy Shinzō Abe o potrzebie rewizji ustawy, spisanej w całkowicie odmiennej sytuacji geopolitycznej na świecie, lecz do dziś stanowiącej fundament krajowego systemu prawa, były już wcześniej powszechnie znane. Niemniej jego majowa wypowiedź przykuła baczną uwagę, gdyż po raz pierwszy japoński lider jasno określił ramy czasowe i kierunek pożądanych zmian, przyjmując między innymi, że misją jego pokolenia jest uporządkowanie prawnego statusu i definitywne uprawomocnienie istnienia Japońskich Sił Samoobrony (Jieitai, 自衛隊). Jego idea dodania do konstytucji zapisów sankcjonujących utrzymywanie własnych sił obronnych w praktyce oznaczałaby konieczność modyfikacji artykułu 9, który w teraźniejszym brzmieniu neguje nie tylko prawo Japonii do prowadzenia wojny, lecz także do posiadania jakiegokolwiek potencjału wojskowego ${ }^{8}$. Mimo wyraźnie określonych prawem ograniczeń nie sposób jednak nie dostrzegać militarnego charakteru Sił Samoobrony, tudzież kwestionować faktu, że od chwili powstania w latach 50. są one kością niezgody w niekończących się polemikach na temat prawnej interpretacji podstaw ich funkcjonowania. W sytuacji gdy ponad $90 \%$ obywateli deklaruje wobec nich zaufanie, premier uznał za wysoce nieodpowiedzialną postawę tych konstytucjonalistów i polityków, którzy stale podnoszą argument o ich niekonstytucyjności, oczekując zarazem heroizmu w zapewnianiu bezpieczeństwa kraju9 . Biorąc pod uwagę społeczne emocje, jakie w 2015 r. towarzyszyły pracom nad Pakietem ustaw o pokoju i bezpieczeństwie (Anzenhoshō kanrenhō, 安全保障関連法), obejmującym między innymi szersze wykorzystanie japońskich kontyngentów w ramach uznania prawa do kolektywnej samoobrony ${ }^{10}$, nie ulega wątpliwości, że koncepcja korekty ustawy zasadniczej ponownie podniesie temperaturę debaty publicznej. I to niezależnie od zapewnień premiera, że nie zamierza zmieniać pacyfistycznych zapisów artykułu 9. Kluczem do sfinalizowania zarysowanych 3 maja 2017 r. założeń będzie zatem nie tylko zręczność premiera w budowaniu kompromisu wśród partii politycznych, które różnie zapatrują się na weryfikację konstytucji, i pozyskanie

dłuższym niż dwa lata” od wejścia aktu w życie. Shigeru Yoshida (premier w latach 1948-1954) nie podjął się tego zadania, oficjalnie negując potrzebę rewizji konstytucji. Tekstu do dziś nie zmieniono.

${ }^{8}$ Konstytucja Japonii, wersja polska przekł. prof. Teruji Suzuki, http://www.pl.emb-japan.go.jp/relations/konstytucja.htm.

9 Pełny tekst wystąpienia Shinzō Abe z 3 maja 2017, https://mainichi.jp/articles/20170504/ $\mathrm{k} 00 / 00 \mathrm{~m} / 010 / 038000 \mathrm{c}$.

${ }^{10}$ Prawo do kolektywnej samoobrony zajmowało uwagę Shinzō Abe już podczas pierwszej kadencji (lata 2006-2007). Premier podkreślał wówczas, że wśród sygnatariuszy Karty Narodów Zjednoczonych Japonia jest jedynym krajem, który z uwagi na ograniczenia konstytucyjne nie ma prawa do obrony swoich sojuszników, co znacząco obniża jej pozycję międzynarodową. Kolektywną samoobronę początkowo umożliwiła zmiana interpretacji zapisów konstytucji w 2014 r., uchwalony zaś w 2015 r. Pakiet ustaw o pokoju i bezpieczeństwie (obowiązujący od 29 marca 2016 r.) usankcjonował prawo do stosowania kolektywnej samoobrony wobec wszystkich sojuszników, rozszerzając też między innymi zakres działań JSS i możliwość wykorzystywania broni. 
w obu izbach parlamentu wsparcia dwóch trzecich deputowanych, lecz również a może przede wszystkim - zdobycie aprobaty narodu, który ostatecznie zadecyduje o zmianie konstytucji w ogólnokrajowym referendum.

Aktualny rozkład sił w japońskim parlamencie sprzyja urzeczywistnieniu planów Shinzō Abe, chociaż nie daje Partii Liberalno-Demokratycznej legitymacji do rewizji konstytucji bez wsparcia innych ugrupowań. Dzięki koalicji z Nową Partią Czystych Rządów (Kōmeitō, 公明党) PLD ma obecnie kwalifikowaną większość w Izbie Reprezentantów, do wymaganej większości w Izbie Radców (Sangiin, 参議院) brakuje jej zaś zaledwie kilku głosów ${ }^{11}$. Partia rządząca może jednak liczyć na wsparcie części opozycji, gdyż po stronie zwolenników aktualizacji ustawy zasadniczej opowiedziała się Japońska Partia Innowacji (Nippon Ishin no kai, 日本維新の会 $)^{12}$, z ramienia której w izbie wyższej zasiada decydujących dla legalizacji dwunastu radców. Poddanie pod głosowanie projektu nowej konstytucji nie jest w tej sytuacji pozbawione szans powodzenia, pod warunkiem, że premier umiejętnie skoordynuje prace nad nowelizacją ze zbliżającym się kalendarzem wyborczym. Pierwszy potencjalny punkt zwrotny może bowiem nadejść pod koniec 2018 r., gdy po wrześniowych wyborach na przewodniczącego PLD w grudniu upłynie pełna kadencja Izby Reprezentantów ${ }^{13}$. I o ile komentatorzy nie zakładają dzisiaj ani przegranej Shinzō Abe podczas partyjnej reelekcji, ani utraty przez PLD większości w izbie niższej w wyborach parlamentarnych, o tyle wielką niewiadomą jest wpływ dopiero zainicjowanej w Japonii dyskusji na przyszłoroczne preferencje wyborców. Wskazówek nie dają też najnowsze sondaże mogące sugerować

${ }^{11}$ Wymagana większość do zmiany konstytucji to dwie trzecie głosów w obu izbach parlamentu (obecnie $310 \mathrm{w}$ izbie niższej i $162 \mathrm{w}$ izbie wyższej). W czerwcu 2017 r. koalicja PLD i NPCZ miała w Izbie Reprezentantów 326 (291/35) z 475 głosów, w Izbie Radców 151 (126/25) z 242 mandatów. W wyniku przedterminowych wyborów do Izby Reprezentantów, które odbyły się w październiku 2017 r., liczba posłów koalicji zmalała o 13 głosów (284/29), niemniej z wynikiem 313 Reprezentantów nie spadła poniżej aktualnie wymaganej większości kwalifikowanej, zob. 2017 Shūinsen kaiken giron honkakuka e [Wybory do Izby Reprezentantów 2017 Dyskusja o zmianie konstytucji nabiera realnych wymiarów], „Mainichi”, 25 października 2017, https://mainichi.jp/senkyo/articles/20171025/ddm/004/070/022000c/.

12 JPI w czerwcu 2017 r. była trzecią siłą w izbie niższej (41 Reprezentantów) i piątą w izbie wyższej (12 Radców). W październikowych wyborach utraciła 30 Reprezentantów i obecnie z 11 mandatami jest siódmym ugrupowaniem w izbie niższej, jednak jej pozycja w izbie wyższej nie uległa zmianie. Korzenie JPI sięgają nieistniejącej już Partii Inicjatyw z Osaki (Ōsaka Ishin no kai, お おさか維新 の会), założonej w 2012 r. przez byłego gubernatora Tokio - Shintarō Ishiharę i byłego mera Osaki - Tōru Hashimoto. W ciągu ostatnich lat uległa wielokrotnym przeobrażeniom, a w 2016 r. część jej członków przeszła do PD. Opowiada się za liberalizmem gospodarczym.

${ }_{13}$ Mimo zapowiedzi premiera, że nie zamierza rozwiązywać niższej izby parlamentu przed zakończeniem pełnej kadencji w grudniu 2018 r. została ona rozwiązana podczas nadzwyczajnej sesji 28 września 2017 r., zaś przedterminowe wybory odbyły się 22 października. Zgodnie z przewidywaniami ich rezultaty nie wpłynęły na zmianę pozycji LDP i premiera. 
co prawda nieznaczną przewagę sympatyków rewizji konstytucji i dodania w niej zapisów legalizujących Japońskie Siły Samoobrony, lecz ukazujące jednocześnie niezdecydowanie społeczeństwa w sprawie oceny postawy szefa rządu w kwestii realizacji jego zamysłu do 2020 r. ${ }^{14}$

W tym świetle majowa wypowiedź Shinzō Abe racjonalnie wpisuje się w harmonogram nadchodzących zdarzeń i świadczy o woli przejęcia przez niego inicjatywy w celu przyśpieszenia prac redakcyjnych, tak by wewnętrzną debatę zamknąć w momencie umożliwiającym połączenie referendum konstytucyjnego z wyborami parlamentarnymi ${ }^{15}$. W przypadku przyjęcia tak napiętego planu czasowego przesądzający o urzeczywistnieniu idei premiera będzie z pewnością zakres proponowanych poprawek. Być może właśnie z tego względu japoński lider wybiórczo skupił się na dwóch zagadnieniach: legalizacji Sił Samoobrony i zagwarantowaniu bezpłatnego szkolnictwa wyższego. Selekcję priorytetowych obszarów można interpretować jako intencję zawężenia dyskursu do tych tematów, które umożliwią osiągnięcie szybkiego kompromisu przez stronników nowelizacji. Godna podkreślenia jest całkowicie nowa w ustach szefa rządu propozycja pozostawienia istniejących zapisów artykułu 9 i uzupełnienia go jedynie o punkty legitymizujące istnienie w kraju sił obronnych. Takie rozwiązanie byłoby zgodne ze stanowiskiem rządowego koalicjanta, Nowej Partii Czystych Rządów, która dopuszcza dopisywanie treści w ustawie zasadniczej, ale sprzeciwia się jakiejkolwiek ingerencji w zawartą w artykule 9 deklarację wyrzeczenia się wojny. Analogicznie wzmianka Shinzō Abe o potrzebie konstytucyjnego zapewnienia bezpłatnego szkolnictwa wyższego jest wyraźnym ukłonem w stronę Japońskiej Partii Innowacji, uznającej tę kwestię za jeden z filarów swojej polityki. Publiczne uwzględnienie tego zagadnienia

${ }^{14}$ Według sondażu Fuji News Network i gazety „Sankei” z 13 i 14 maja 2017 r., na pytanie o ocenę premiera, który jako szef PLD ogłosił wolę rewizji artykułu 9 i wprowadzenia w życie nowej konstytucji do 2020 r., taki sam procent respondentów (46,9\%) odpowiedział, że docenia bądź nie docenia jego postawy. W tej samej ankiecie za nowelizacją opowiedziało się $49,8 \%$ pytanych przy $44 \%$ głosów negatywnych, przy czym 59,1\% badanych stwierdziło, że aktualna konstytucja nie przystaje do obecnych czasów. Niejednoznaczny obraz dają też wyniki badań gazet „Asahi” i „Yomiuri” z połowy maja 2017 r., patrz: https://www.fnn-news.com/yoron/inquiry170515.html, https://www.j-cast.com/2017/05/16298078.html.

15 Zgodnie z konstytucją referendum musi się odbyć między 60. a 180. dniem po uchwaleniu projektu przez parlament, przy czym termin wyborów jest zależny od upływu kadencji w poszczególnych izbach. W związku z tym, że wybory do izby niższej odbyły się przed zakładanym na grudzień 2018 r. terminem, możliwe jest połączenie referendum konstytucyjnego z wyborami do izby wyższej parlamentu, której kadencja upływa w lipcu 2019 r., patrz: Shushō „nijūnen ni shinkenpō”, jitsugen nao hādoru takaku, minshin nado mōhanpatsu, hatsugi no jiki shōten [w cyklu: Premier „Nowa konstytucja w 20 roku” - przed urzeczywistnieniem jeszcze wysoka poprzeczka, ostry sprzeciw PD i innych, fokus na okresie uchwalenia], „Nikkei”, 5 maja 2017, http://www.nikkei.com/article/DGKKZO1604664004052017PE8000/. 
przez japońskiego premiera będzie zapewne znaczącym krokiem ku osiągnięciu porozumienia o aktualizacji siedemdziesięcioletniego dokumentu ${ }^{16}$.

W tym kontekście nie dziwi też milczenie premiera o ewentualnej potrzebie zmian wynikających z wyrażenia przez cesarza Akihito woli zrzeczenia się tronu ${ }^{17}$. Japońska konstytucja, która zasadniczo definiuje zakres aktywności monarchy w sprawach państwowych, przyznając mu zarazem status „symbolu Państwa i jedności narodu”18, nie dopuszcza możliwości abdykacji ${ }^{19}$. Co za tym idzie, zagwarantowanie cesarzowi nowego konstytucyjnego prawa mogłoby wywołać wielowątkową polemikę na temat rozumienia „symbolicznej roli” systemu cesarskiego we współczesnej Japonii ${ }^{20}$. Złotym środkiem pozwalającym na sprawne rozwiązanie zaistniałego $\mathrm{w}$ sierpniu 2016 r. problemu jest przegłosowana 9 czerwca 2017 r. Specjalna Ustawa w sprawie abdykacji (Tai'i tokureiho, 退位特例法), która tymczasowo zamyka temat, jednorazowo zatwierdzając abdykację przeszło osiemdziesięcioletniego monarchy na rzecz syna, księcia Naruhito.

Zapobiegliwość japońskiego przywódcy w ograniczaniu wpływu czynników, które mogą opóźnić procedowanie planów związanych z korektą konstytucji, nie wydaje się w tak złożonej sytuacji przesadzona. Tym bardziej że poza pozyskaniem wsparcia sojuszników premier będzie musiał się zmierzyć też z ostrym sprzeciwem opozycji niepodzielającej jego przekonania o potrzebie aktualizacji ustawy zasadniczej. Symptomatyczna była już pierwsza reakcja szefowej Partii Demokratycznej (Minshintō, 民進党) ${ }^{21}$ Renhō Muraty, która bezpośrednio po majowym wystąpieniu premiera zasugerowała, że rzeczywistą pobudką działań Shinzō Abe jest chęć

${ }^{16}$ Nowy ton dostrzegli przywódcy obu partii deklarujących wolę dialogu. Szef NPCZ Natsuo Yamaguchi stwierdził, że nowa koncepcja jest różna od wcześniejszych propozycji PLD i jest warta debaty parlamentarnej. Sekretarz generalny POJ Nobuyuki Baba wyraził zaś zadowolenie, że stanowisko jego partii zostało uznane, patrz. Shushō ,nijünen ni shinkenpō”, higan tassei e jiron zenmen, kyūjō, tōsōan kodawarazu [w cyklu: Premier „Nowa konstytucja w 20 roku” - dla realizacji gorącego pragnienia własne zdanie na pierwszym miejscu, art. 9., bez przywiązania do projektu partii] „Nikkei”, 5 maja 2017, http://www.nikkei.com/article/DGKKASFS03H26_T00C17A5PE8000/.

17 Cesarz Akihito wyraził chęć ustąpienia z tronu w telewizyjnym orędziu do narodu 8 sierpnia 2016 r. Jako uzasadnienie podał zaawansowany wiek uniemożliwiający prawidłowe wykonywanie obowiązków, patrz: strona internetowa Urzędu ds. Dworu Cesarskiego, pełny tekst wystąpienia cesarza Akihito (tłum. ang.), http://www.kunaicho.go.jp/page/okotoba/detailEn/12.

18 Konstytucja Japonii...

19 Japońskie prawodawstwo dopuszcza wyłącznie możliwość regencji. Problematykę abdykacji kompleksowo przedstawia artykuł Małgorzaty Szmidt Rok 2019 poczatkiem nowej ery $w$ dziejach Japonii? Abdykacja cesarza Akihito i jej konsekwencje w niniejszym tomie „Azji-Pacyfiku”.

${ }^{20}$ Abe wa shōchō tennōsei wo dō suru ki ka" [Co zamierza zrobić Abe z symbolicznym systemem cesarskim?], „Sentaku” 2016, nr 9, s. 52-53.

${ }^{21}$ PD po utracie władzy w 2012 r. reformowała się kilkakrotnie, ostatecznie 27 marca 2016 r. łącząc się z Partią Innowacji (Ishin no tō, 維新の党), częścią członków Partii Wizji Reform (Kaikaku Kesshū no kai, 改革結集の会) oraz z grupą posłów niezrzeszonych. Zmieniła wówczas nazwę 
pozostawienia po sobie spuścizny. Zastrzeżenia krytyków z PD dotyczą zwłaszcza postawy premiera, który pragnie sam moderować prace nad nowelizacją, nie uwzględniając faktu, że w komisjach parlamentarnych dyskusja nad koniecznością zmiany konstytucji nie została jeszcze wyczerpana. Równie negatywny stosunek wyraził przewodniczący Japońskiej Partii Komunistycznej (Nihon Kyōsantō, 日本共産党) Kazuo Shii, deklarując, że zrobi wszystko, by stanąć na drodze realizacji koncepcji Shinzō Abe. Konfrontacyjny kurs politycznych adwersarzy jest więc dla szefa rządu sygnałem, że wśród elementów ryzyka musi uwzględnić także opinię przewodniczącego Komisji do spraw Konstytucji w Izbie Reprezentantów (Shūgiin kenpō shinsakai, 衆議院憲法審査会), wykluczającego możliwość zgłoszenia do narodowego referendum projektu nowej konstytucji tak długo, póki będzie on obiektem sporu opozycji i partii rządzącej ${ }^{22}$.

Wobec burzliwie zapowiadającej się debaty legislatorów nasuwa się pytanie, czy opozycja kwestionująca zamysł korekty konstytucji może realnie powstrzymać inicjatywę premiera. Wspomniana już Partia Demokratyczna ma w każdej z izb około 20\% mandatów, podczas gdy Japońska Partia Komunistyczna dysponuje 4-5\% głosów ${ }^{23}$. Obiektywnie parlamentarne weto nie stanowi w tym wypadku rzeczywistego zagrożenia, chociaż siła opozycji może tkwić w jej oddziaływaniu na opinię publiczną, nawet jeśli na razie trudno ocenić potencjał jej wpływu. Słabością może okazać się jednak powszechne rozczarowanie trzyletnim okresem rządów Partii Demokratycznej, manifestowane drastyczną utratą przez nią społecznego zaufania ${ }^{24}$. Nieudolność we wdrażaniu obiecanych reform, łączona ze stylem polityki okrzykniętym „,polityką niezdecydowania" 25 odcisnęła na wizerunku partii na tyle trwałe piętno, że w oczach

z Minshutō (民主党) na Minshintō (民進党), ale jej angielska nazwa - The Democratic Party - pozostała niezmieniona. Prawnie jest kontynuatorką PD założonej w 1996 r.

22 Shushō ,nijünen ni shinkenpō”....

${ }^{23}$ W czerwcu 2017 r. PD miała w Izbie Reprezentantów 95 głosów (z 475), JPK 21; w Izbie Radców PD miała 50 (z 242) mandatów, JPK zaś 14. W wyniku październikowych wyborów do Izby Reprezentantów, PD utraciła swoich Reprezentantów, których część znalazła się w nowo powstałych formacjach opozycyjnych: Partii Nadziei (Kibō no tō, 希望の党) i Partii Konstytucyjno-Demokratycznej (Rikken Minshutō, 立憲民主党) oraz wśród posłów niezrzeszonych, wyniki wyborów: http://www.asahi.com/ senkyo/senkyo2017/no tō, 希望の党).

${ }^{24}$ Gdy PD obejmowała władzę we wrześniu 2009 r., poparcie dla niej wynosiło 42\%, w maju 2017 r. zaś ok. 8\% - przy ponad $41 \%$ poparcia dla PLD i ponad $35 \%$ respondentów niepopierających żadnego ugrupowania (badania FNN i gazety „Sankei” z maja 2017 r.), patrz: http://www.nhk.or.jp/ bunken/yoron/political/2009.html, https://www.fnn-news.com/yoron/inquiry170515.html.

25 Jap. kimerarenai seiji (決められない政治), thumaczone jako ,polityka niezdecydowania”, szerzej odnosi się do nieefektywnego stylu rządzenia PD, który charakteryzował brak zdolności podejmowania decyzji i realizacji reform. 
wyborców wciąż nie udało jej się zrehabilitować ${ }^{26}$. Tym bardziej że w ciągu ostatnich czterech lat PD ani nie zdołała opracować nowatorskiej wizji w kwestiach gospodarki, polityki zagranicznej czy też obronności kraju, ani znaleźć nietuzinkowego przywódcy, który byłby przeciwwagą dla obecnego premiera ${ }^{27}$. Wśród obserwatorów politycznych pojawiają się wręcz głosy, że de facto siła Shinzō Abe tkwi nie w jego personalnych atutach lub atrakcyjności programu, lecz w słabości jego politycznych rywali. Faktem jest, że wewnętrzna scena pozbawiona jest dziś dynamiki i nie sposób doszukiwać się na niej sugestywnych postaci oferujących godną rozważenia alternatywę dla propozycji szefa rządu. Jedną z niewielu osób zaczynających zaznaczać swoją obecność na krajowym forum jest nowa gubernator Tokio Yuriko Koike, która pozytywnie zaskoczyła rodaków stanowczą postawą podczas wyjaśniania nieprawidłowości związanych z relokacją tokijskiego targu rybnego Tsukiji. Aczkolwiek za wcześnie jeszcze na ocenę jej politycznego kapitału, który w dużej mierze będzie zależeć od zdolności zbudowania przez nią własnego, silnego zaplecza, jak i od jakości zarządzania największą metropolią w kraju ${ }^{28}$. W sytuacji tak daleko posuniętej przewidywalności sceny politycznej nie zaskakuje więc malejące zainteresowanie społeczeństwa polityką, które przejawia się postępującym spadkiem frekwencji wyborczej i stopniowym powiększaniem grona osób niedeklarujących sympatii dla jakiejkolwiek partii ${ }^{29}$.

26 Jednym z elementów, które wpłynęły na zwycięstwo PD (Minshutō) we wrześniu 2009 r. i zdobycie rekordowej większości parlamentarnej (308 z 480 mandatów), był program zawierający obietnice poprawy warunków życia po 20 latach stagnacji gospodarczej, nazywanej w Japonii straconym dwudziestoleciem. Trzech kolejnych premierów z PD (Yukio Hatoyama, Naoto Kan,Yoshihiko Noda) nie było jednak w stanie zrealizować obiecanych reform. Nałożył się na to kryzys spowodowany awarią elektrowni atomowej w Fukushimie po katastrofalnym trzęsieniu ziemi 11 marca 2011 r. Po trzech latach rządów poparcie dla PD spadło na tyle, że w wyborach parlamentarnych do izby niższej w 2012 r. uzyskała tylko 57 głosów.

${ }^{27}$ Minshintō kara dete konai „Puran B” wa habatsu ga tsukuru ka? [Czy „Plan B”, którego nie wysuwa PD, opracują frakcje partyjne?], „Nikkei”, 11 czerwca 2017, http://www.nikkei.com/article/DGXKZO17546690Q7A610C1EA3000/.

28 Jest pierwszą kobietą na stanowisku gubernatora Tokio (od 31 lipca 2016 r.), wybraną mimo braku rekomendacji macierzystej partii (PLD). Po objęciu urzędu rozpoczęła dochodzenie w sprawie skażenia chemicznego w miejscu planowanej relokacji targu Tsukiji, czasowo wstrzymując projekt. Odeszła z PLD 1 czerwca 2017 r., obejmując funkcję przewodniczącej własnego ugrupowania Najpierw Tokijczycy (Tomin Fāsuto no kai, 都民ファーストの会). Dzięki aktywnemu wsparciu kampanii wyborczej do Rady Metropolii Tokio (wybory 2 lipca 2017 r.) członkowie jej ugrupowania zdobyli 53 ze 127 mandatów (42\%), odbierając PLD dotychczasową pierwszą pozycję w Radzie Metropolii Tokio.

${ }^{29}$ Frekwencja w latach 2009 - 69,28\%, 2012 - 59,32\%, 2014 - 52,66\% (wybory do izby niższej), patrz: strona internetowa Ministerstwa Spraw Wewnętrznych i Łączności, http://www.soumu.go.jp/senkyo/senkyo_s/news/sonota/ritu/. Wzrasta też liczba wyborców niewspierających żadnej partii 
Na tym tle zwraca uwagę dotychczasowe stabilne poparcie społeczne dla gabinetu Shinzō Abe, wahające się w minionych latach między $40 \%$ a 55\% ${ }^{30}$. Momentem znaczącego, kilkumiesięcznego obniżenia popularności premiera był okres poprzedzający uchwalenie rzeczonego Pakietu ustaw o pokoju i bezpieczeństwie w 2015 r., gdy liczba przeciwników przewyższyła grupę popleczników szefa rządu, a różnica w słupkach wsparcia sięgnęła ponad 10 pkt procentowych ${ }^{31}$. Tymczasem przyjęcie ustawy ostudziło emocje na tyle, że wkrótce poziom aprobaty wrócił do wartości wyjściowych, oscylując w kolejnych latach wokół 50\%. Zaznaczenia wymaga niemniej uderzające pogorszenie notowań premiera przy wyraźnym wzroście liczby osób niepopierających jego administracji, odnotowane w czerwcowych sondażach. Spadek akceptacji osiągnął nawet wartości dwucyfrowe, a - według części badań - grupa oponentów Shinzō Abe znów przewyższyła krąg jego sympatyków ${ }^{32}$. Z jednej strony jest to z pewnością echo uchwalonej 15 czerwca $2017 \mathrm{r}$. W niezrozumiałym pośpiechu Ustawy antykonspiracyjnej (,Kyōbōzai” hō,「共 謀罪」法 $)^{33}, \mathrm{z}$ drugiej wpływ podnoszonych przez opozycję i skrupulatnie podchwytywanych przez media skandali, w których premier Abe zdaje się odgrywać pierwszoplanową rolę. Pierwszy z nich, związany ze sprzedażą szkole Moritomo

(w poprzednich latach ok. 30-35\%, w czerwcu 2017 r. 40,8\% według badania telewizji publicznej NHK z 9 czerwca 2017), patrz: http://www.nhk.or.jp/bunken/research/yoron/political/2017.html.

${ }^{30}$ Jak dotąd stabilna była też liczba osób niezadowolonych z obecnej administracji (ok. 30-35\%), patrz: popularność gabinetów (lata 1988-2017) na stronie internetowej TV Asahi, http://www.tv-asahi.co.jp/hst/poll/graph_naikaku.html.

31 Zwrot nastąpił w lipcu 2015 r. podczas prac nad legalizacją wspomnianego prawa do kolektywnej samoobrony, umożliwiającej JSS obronę sojuszników w rejonach konfliktów zbrojnych. 47\% społeczeństwa nie poparło wówczas gabinetu Abe, przy wsparciu 36,1\%. Uchwaleniu ustawy towarzyszyły demonstracje. Patrz: Huge Protest in Tokyo Rails against PM Abe's Security Bills, Agencja Reutera, 30 sierpnia 2015, http:/www.reuters.com/article/us-japan-politics-protest-idUSKCN0QZ0C320150830.

32 Według badania opinii publicznej telewizji NHK z 9 czerwca 2017 r. poparcie gabinetu deklarowało 48\% badanych, lecz według sondaży przeprowadzonych 16-18 czerwca 2017 r. przez gazety „Asahi”, „Sankei”, „Mainichi”, „,Yomiuri”, „Nikkei”, agencję prasową Kyōdō oraz stacje telewizyjne Fuji, Asahi, Tokio i Nihon TV spadło ono o 6-12 punktów procentowych w stosunku do badań majowych. Wśród czytelników gazet „Asahi”, „Mainichi” i „Tokio” liczba oponentów administracji Abe znacznie przekroczyła grupę jej zwolenników (skrajne wartości to 77\% do 5\% w sondażu gazety „Tokio”), patrz: http://www3.nhk.or.jp/news/html/20170612/k10011014961000.html, http:// www.asahi.com/articles/ASK6M55KQK6MUTFK009.html; https://news.yahoo.co.jp/byline/yoneshigekatsuhiro/20170620-00072316/.

${ }^{33}$ Ustawę przyjęto $\mathrm{w}$ trybie pilnym, z pominięciem zwyczajowego głosowania w komisji do spraw sprawiedliwości. Według rządzących jej wprowadzenie wynika z konieczności zapewnienia bezpieczeństwa antyterrorystycznego podczas igrzysk w 2020 r., ale budzi ona kontrowersje z uwagi na zagrożenie dla swobód obywatelskich. W sondażu TV Asahi (przypis 35) 65\% ankietowanych stwierdziło, że nie rozumie założeń ustawy, patrz: też Ustawa antykonspiracyjna przyjęta, http://japonia-online.pl/news/5688. 
Gakuen w Osace państwowej ziemi po zaniżonej cenie, nieco stracił na sile wobec eskalacji kolejnego, obnażającego domniemaną ingerencję szefa rządu w proces wydania pozwolenia na otwarcie wydziału weterynarii w specjalnej strefie ekonomicznej przez należącą do znajomego premiera akademię Kake Gakuen z Okayamy $^{34}$. I choć premier wyraźnie odciął się od kierowanych pod jego adresem zarzutów, na światło dzienne wychodzą dokumenty podważające jego wiarygodność, a najnowsze badania opinii publicznej wskazały, że do 65\% ankietowanych nie trafiły wyjaśnienia szefa rządu ${ }^{35}$. Wprawdzie na razie pozycja Shinzō Abe nie wydaje się jednoznacznie zagrożona, lecz dalsza erupcja niezadowolenia może zachwiać jego administracją, odbierając mu nawet mandat do rządzenia, nie wspominając o zamiarze wprowadzenia nowej konstytucji w $2020 \mathrm{r}$.

Prawdą jest jednak, że dziś niełatwo znaleźć w Japonii odpowiedź na pytanie: kto miałby stać u sterów rządu, jeśli nie Shinzō Abe? Na wizerunek przywódcy oddanego sprawom kraju premier pracuje od chwili powrotu do władzy w 2012 r., niejednokrotnie odwołując się do autorskiej polityki gospodarczej, zwanej Abenomics, i regularnie komunikując społeczeństwu hasła jej nowych założeń ${ }^{36}$. Co prawda, nierzadkie są głosy krytyki za brak skuteczności jego programu ekonomicznego, lecz abstrahując od trafności uwag ekspertów, wzrost wartości akcji i deprecjacja jena przełożyły się na zwiększenie rentowności przedsiębiorstw i poprawę warunków zatrudnienia. Przeciętny wyborca dostrzega zatem rekordowo niskie bezrobocie, wzrost średniego wynagrodzenia czy poprawę wskaźnika zatrudnienia absolwentów uczelni ${ }^{37}$. Z tego względu nie zdumiewa popularność premiera,

34 Tłem obu skandali jest podejrzenie naruszenia zasady neutralności urzędników państwowych pod niewyjaśnionym wpływem premiera lub bliskich mu osób, patrz: Japan PM Shinzō Abe Embroiled in Land-sale Scandal, CNN, 24 marca 2017, http://edition.cnn.com/2017/03/22/asia/japan-school-scandal/index.html; Abe under Fire over Shady Dealings Claims, „Japan Today”, 16 czerwca 2017, https://japantoday.com/category/politics/japan-pm-under-fire-over-shady-dealings-claims.

${ }^{35}$ Co więcej, 60-65\% ankietowanych opowiedziało się za prześwietleniem sprawy przez powołaną w tym celu komisję parlamentarną (według badań stacji telewizyjnych NHK i TV Asahi z maja i czerwca 2017 r.), patrz: http://www3.nhk.or.jp/news/html/20170612/k10011014961000.html; http:// www.tv-asahi.co.jp/hst/poll/201705/index.html.

${ }^{36}$ Abenomics (Abenomika) - od połączenia nazwiska premiera $\mathrm{z}$ angielskim słowem economics. Główne założenia (tzw. trzy strzały) obejmują ożywienie gospodarki przez: 1. wyjście z deflacji i osiągnięcie dwuprocentowej stopy inflacji; 2 . powrót do elastycznej polityki fiskalnej; 3. efektywną strategię rozwoju gospodarczego. „Trzecia strzała” bywa regularnie aktualizowana, a najnowsze hasła to: rewitalizacja prowincji, aktywizacja całego społeczeństwa i reforma stylu pracy.

${ }^{37}$ Krytyka dotyczy zwłaszcza strategii prorozwojowej, nieprzynoszącej zgodnych z założeniami rezultatów. Uwagę zwraca m.in. niewystarczająca deregulacja pod kątem wsparcia rewolucji technologicznej i stwarzanie przedsiębiorstwom nowych szans biznesowych oraz tolerowanie skostniałych układów, jak i słaby wzrost gospodarczy, bez którego niemożliwe jest uzdrowienie finansów publicznych. Patrz: Trzecia pozycja... Pozytywne dane w 2016 r. to m.in. bezrobocie - 3,1\%, średnie roczne wynagrodzenie - wzrost o 1,3\% (dane za 2015 r.), wskaźnik zatrudnienia absolwentów 
tym bardziej że niejednokrotnie pokazywał on obywatelom osobiste zaangażowanie, odgórnie czuwając nad realizacją krajowej polityki czy reprezentując zdecydowane stanowisko Japonii na forum międzynarodowym. Jest on także ceniony wewnątrz partii rządzącej za przywiązywanie wagi do harmonijnej współpracy. Równocześnie nie umyka uwagi jego całkowity brak zaangażowania w wychowywanie następców ${ }^{38}$. Niełatwo zatem o zmiennika, który przejmie pałeczkę w partyjnej sztafecie, chociaż jednym z bardziej obiecujących kandydatów wydaje się minister spraw zagranicznych Fumio Kishida ${ }^{39}$, który zadeklarował gotowość do objęcia teki premiera po zakończeniu misji obecnego szefa rządu. Wśród wymienianych osób pojawiają się też nazwiska wicepremiera i ministra finansów Tarō Asō, byłego przewodniczącego PLD Sadakazu Tanigakiego i zdobywającego coraz większą życzliwość ogółu Shinjirō Koizumiego, syna byłego premiera i politycznego mentora Shinzō Abe ${ }^{40}$. Czy którykolwiek z nich odegra wiodącą rolę w tworzeniu ,ery po Abe”, czas pokaże.

Obraz sceny politycznej w Japonii pod koniec czerwca 2017 r. skłania do refleksji, że choć przez ostatnie cztery lata zasadniczo był to teatr jednego aktora, to najbliższe miesiące mogą zaważyć zarówno na przyszłości japońskiego premiera, jak i na dyskusji o nowelizacji konstytucji. Shinzō Abe od 2012 r. jest centralną postacią na forum krajowym, a społeczne poparcie dla jego gabinetu dawało mu legitymację do realizowania przyjętych założeń, do których 3 maja 2017 r. dodał on zmianę ustawy zasadniczej. Czerwcowa reakcja opinii publicznej na świeżo ujawnione skandale i forsowanie budzącego kontrowersje prawa to jednak czytelny sygnał, że szef rządu jest bacznie obserwowany przez naród, a jego władza, mimo słabej opozycji, nie jest nieograniczona. Czy spadek poparcia z czerwcowych sondaży będzie na tyle trwały, by zniweczyć obiecującą przyszłość Shinzō Abe, w dużej mierze zależeć będzie od stylu, w jakim zmierzy się on z zaistniałym kryzysem. Przywrócenie społecznego zaufania jest niemniej niezbędnym warunkiem zarówno utrzymania władzy, jak i rozpoczęcia konstruktywnej dyskusji nad zmianą konstytucji, nie wspominając o powodzeniu referendum konstytucyjnego.

- ponad 95\%. Patrz: strony Biura Statystyki w Ministerstwie Spraw Wewnętrznych i Łączności, Naczelnej Izby Administracji Skarbowej i firmy Recruit, http:/www.stat.go.jp/data/roudou/sokuhou/ tsuki/, http://www.nta.go.jp/kohyo/press/press/2016/minkan/; https://www.recruitcareer.co.jp/news/ pressrelease/2017/170414-01/.

${ }^{38}$ Uważa się, że premier Abe wzoruje się na Jun'ichirō Koizumim, który rządził z poziomu kancelarii Rady Ministrów, ignorując wertykalne powiązania w ministerstwach i realizując swoją strategię. Dotyczyło to też polityki zagranicznej. Premier Koizumi przywiązywał jednak wagę do konkurencji wewnątrzpartyjnej, której osią była rywalizacja potencjalnych następców. Shinzō Abe dba o wewnątrzpartyjną równowagę, jednocześnie nie dając pola ewentualnym rywalom i następcom. Patrz: Abe shushō zainin...

39 Od września 2017 r. przewodniczący Rady Politycznej ds. Strategii PLD.

${ }^{40}$ Minshintō kara dete konai ,Puran B”... 
Jeszcze pod koniec maja 2017 r. mogło się wydawać, że czujący się pewnie w swojej roli premier jest o włos od realizacji planów związanych z rewizją konstytucji. Przy teoretycznie zagwarantowanej większości parlamentarnej mógł dodatkowo liczyć na większe zrozumienie obywateli dla posunięć podnoszących bezpieczeństwo kraju w obliczu prób balistycznych powtarzanych przez reżim Korei Północnej. Tymczasem dzisiaj otwarte wydaje się pytanie, czy to Shinzō Abe będzie witał w Tokio sportowców z całego świata podczas inauguracji igrzysk olimpijskich w 2020 r. Pomijając już kwestię tego, czy olimpijski znicz zapłonie w Japonii tak jednoznacznie jak dziś deklarującej w konstytucji pacyfistyczną postawę.

\section{Summary}

\section{Political changes in Japan: the era of Shinzō Abe and debate on amending the Constitution - overview at mid-year 2017}

On May 3, 2017, Japan's Prime Minister Shinzō Abe announced his willingness to amend the Japan's Constitution by 2020. This article presents an analysis of main issues related to PM's statement, including:

- scope of considered amendments and their impact on Article 9,

- ratification chances and timeline for revision,

- reactions of main political party leaders,

- influence of emperor's abdication,

- main risks of Abe's plan failure.

The author takes also a closer look at recent drop in PM's approval ratings and comes to the conclusion that the erosion of public trust could be a turning point not only for constitutional revision but also for Shinzō Abe's future. 


\section{Bibliografia}

1. Abe under Fire over Shady Dealings Claims, „Japan Today”, 16 czerwca 2017.

2. Abe wa shōchō tennōsei wo dō suru ki ka" [Co zamierza zrobić Abe z symbolicznym systemem cesarskim?], „Sentaku” 2016, nr 9.

3. http:// www.tv-asahi.co.jp/hst/poll/201705/index.html.

4. http://www.asahi.com/articles/ASK6M55KQK6MUTFK009.html.

5. http://www.nhk.or.jp/bunken/research/yoron/political/2017.html.

6. http://www.nhk.or.jp/bunken/yoron/political/2009.html, https://www.fnn-news. com/yoron/inquiry $170515 . \mathrm{html}$.

7. http://www.nta.go.jp/kohyo/press/press/2016/minkan/.

8. http://www.soumu.go-.jp/senkyo/senkyo_s/news/sonota/ritu/.

9. http://www.stat.go.jp/data/roudou/sokuhou/ tsuki/.

10. http://www.tv-asa- hi.co.jp/hst/poll/graph_naikaku.html.

11. http://www3.nhk.or.jp/news/html/20170612/k10011014961000.html.

12. http://www3.nhk.or.jp/news/html/20170612/k10011014961000.html.

13. https://news.yahoo.co.jp/byline/yone-shigekatsuhiro/20170620-00072316/.

14. https://www.recruitcareer.co.jp/news/ pressrelease/2017/170414-01/.

15. Huge Protest in Tokyo Rails against PM Abe's Security Bills, Agencja Reutera, 30 sierpnia 2015, http://www.reuters.com/article/us-japan-politics-protest-idU-SKCN0QZ0C320150830.

16. Japan PM Shinzō Abe Embroiled in Land-sale Scandal, CNN, 24 marca 2017, http://edition.cnn.com/2017/03/22/asia/japan-school-scandal/index.html.

17. Jimintō, sōsaininki ,renzoku sanki, kyūnen” ni enchō tōtaikai de ryōshō $[\mathrm{Na}$ konwencji partyjnej zatwierdzono wydłużenie kadencji przewodniczącego PLD do „trzech kadencji z rzędu, dziewięciu lat”], „Asahi”, 5 marca 2017, http:// www.asahi.com/articles/ASK353DVPK35UTFK001.html.

18. Konstytucja Japonii, przekł. prof. Teruji Suzuki, http://www.pl.emb-japan.go-. jp/relations/konstytucja.htm.

19. Sengo san 'i , nagaki o motte tōtoshi to sezu” [Trzecia pozycja po wojnie „długo nie oznacza wartościowo”], „Nikkei”, 27 maja 2017, http://www.nikkei.com/ article/DGXKZO16908780W7A-520C1EA1000/.

20. Shinzō Abe, Piękny kraj Shinzō Abe-japońska wizja przyszłości?, [w:] K. Gawlikowski, M. Ławacz (red.), Japonia na początku XXI wieku. Polityka, gospodarka, społeczeństwo i stosunki z Polską, Torun 2008. 